\title{
VISUALISASI PEMBELAJARAN TAJWID DALAM MEMBACA ALQUR'AN BERBASIS MULTIMEDIA
}

\author{
Iwan Purwanto*1 \\ ${ }^{*}$ Program Studi Sistem Informasi \\ Fakultas Ilmu Komputer \\ Universitas Bandar Lampung \\ Jl. Zainal Abidin Pagar Alam No. 26 \\ Labuhan Ratu Bandar Lampung 35142
}

\begin{abstract}
Metode pembelajaran yang digunakan sangat menetukan keberhasilan penyampaian materi, baik dilingkungan sekolah, instansi - instansi pendidikan agama dan juga pembelajaran di rumah. Dengan demikian, seiring dengan perkembangan zaman maka menuntut segala sesuatunya lebih canggih dan menarik. Hal yang diperlukan untuk menunjang kegiatan tersebut yaitu berupa inovasi - inovasi dalam metode pembelajaran. Teknologi komputer dapat digunakan untuk menunjang kegiatan tersebut yaitu sebagai fasilitas pengembangan suatu perangkat lunak dalam metode pembelajaran, yaitu dengan membuat suatu program aplikasi metode pembelajaran yang memberikan kesan dan trik - trik pembelajaran dalam penyampaian materi sesuai dengan materi yang akan disajikan. Taman Pendidikan Alqur'an mengajarkan segala sesuatu mengenai ajaran agama Islam untuk anak - anak, salah satu yang dibahas adalah ilmu tajwid yang mempelajari cara membaca huruf hijaiyah baik yang berdiri sendiri maupun yang tersambung. Setiap siswa akan diajarkan ilmu tajwid, namun tidak semua siswa akan dengan mudah menerima materinya. Hal ini disebabkan karena tidak semua siswa akan mengerti penyampaian materi yang disajikan dengan metode pembelajaran yang tidak kondusif, cenderung berulang - ulang dan membosankan. Akibatnya proses belajar akan terhambat. Masalah diatas perlu ditanggulangi yaitu dengan membuat sebuah alat bantu pembelajaran yang dapat membantu proses belajar tajwid dalam membaca Alqur'an yaitu dengan pembuatan Visualisasi Pembelajaran Tajwid Dalam Membaca Alqur'an Berbasis Multimedia. Perancangan sistem ini menggunakan beberapa alat diantaranya flowchart, map situs, Entity Relationship Diagram (ERD), dan relasi antar tabel. Pengolahan animasi menggunakan Macromedia Flash 8, pengolahan suara menggunakan Adobe Audition dan pengolahan data menggunakan Microsoft Visual Basic 6.0 dengan database Microsoft Acces.
\end{abstract}

Keywords : alquran berbasis multimedia, Entity Relationsip Diagram, Flowchart,Adobe Audition.

\section{PENDAHULUAN}

Zaman modern ini mengharuskan manusia untuk melengkapi hidupnya dengan Ilmu Pengetahuan dan Teknologi (IPTEK) supaya mampu bersaing dalam menghadapi tantangan globalisasi, dan untuk menyempurnakan ilmu pengetahuan dan teknologi maka manusia harus mempunyai Iman dan Taqwa (IMTAQ) supaya dapat tetap berada dalam jalan yang benar. Masing - masing kepercayaan iman dan taqwa setiap agama diatur dalam kitab suci masing - masing agama.

Agama islam mempunyai kitab suci yaitu Alqur'an. Alqur'an adalah pedoman bagi setiap muslim karena didalam Alqur'an berisi tentang ajaran dan aturan agama islam. Sudah menjadi kewajiban bagi setiap muslim untuk belajar membaca dan memahami isi kandungan Alqur'an. Membaca Alqur'an harus dengan benar karna jika membacanya salah maka akan mempunyai arti yang berbeda. Cara membaca Alqur'an harus sesuai dengan aturan - aturan ilmu tajwid.

Definisi tajwid menurut Abdullah Asy'ari BA (1987:7) adalah "ilmu yang digunakan untuk mengetahui bagaimana sebenarnya membunyikan huruf - huruf dengan betul, baik huruf yang berdiri sendiri maupun huruf dalam rangkaian".

Mempelajari ilmu tajwid wajib hukumnya bagi setiap muslim, tidak membedakan jenis kelamin maupun umur. Ilmu tajwid sudah menjadi kurikulum yang wajib diajarkan di sekolah sekolah, dari sekolah dasar hingga sekolah menengah pada pelajaran Pendidikan Agama Islam, tetapi tidak diprioritaskan. Selain itu ilmu tajwid juga diajarkan di TPA (Taman Pendidikan Al-qur'an), namun proses pembelajarannya masih sangat sederhana sehingga membuat siswa merasa bosan. Keterbatasan waktu dan para pengajar serta 
kesederhanaan metode pembelajaran membuat kita sangat terbatas mendapatkan ilmu tajwid.

Melihat kenyataan bahwa media pembelajaran tajwid yang ada saat ini sangat sederhana maka perlu ada pergeseran paradigma pembelajaran, untuk itu perlu dibuat suatu metode pembelajaran tajwid yang baru dan lebih maju. Bersamaan dengan adanya kemajuan teknologi maka pemikiran orang semakin maju. Hal - hal yang bersifat manual semakin ditinggalkan, mereka lebih tertarik dengan hal - hal yang bersifat teknologi. Salah satu bentuk teknologi adalah komputer. Komputer sudah menjadi bagian penting dan sudah dirasakan manfaatnya, termasuk dalam dunia pembelajaran.

Komputer di dalam dunia pembelajaran digunakan sebagai tutorial atau inovasi - inovasi pembelajaran. Dengan komputer maka dapat dibuat metode pembelajaran tajwid berbasis multimedia, representasi materi kedalam bentuk tulisan, gambar maupun verbal. Hal ini dapat membantu para pengajar untuk menyampaikan materi kepada siswanya dengan lebih mudah. Siswa akan menerima materi dengan senang dan tidak bosan. Jika antara pengajar dan siswa interaksinya baik maka tujuan dari pembelajaran akan tercapai.

Berdasarkan uraian di atas, maka penulis menyimpulkan untuk mengambil judul "Visualisai Pembelajaran Tajwid Dalam Membaca Alqur'an Berbasis Multimedia".

\section{Metode pengumpulan Data}

Penulisan skripsi ini diperlukan data dan informasi serta keterangan yang berhubungan dengan masalah yang akan dibahas. Adapun metode yang di gunakan dalam pengumpulan data tersebut antara lain :

- Pengamatan

- Wawancara

- Tinjauan pustaka

\section{LANDASAN TEORI}

\section{a. Pengertian Sistem}

Ada dua kelompok pendekatan dalam mendefinisikan sistem, yaitu pendekatan yang menekankan pada prosedurnya dan pendekatan yang menekankan pada komponen atau elemennya. Pendekatan sistem yang lebih menekankan pada prosedurnya dikemukakan oleh
Jerry Fitzgerald, Arda F. Fitzgerald dan Warren D Stalling Jr, yang mendefinisikan sistem sebagai suatu jaringan kerja dan prosedur yang saling berhubungan, berkumpul bersama-sama untuk melakukan suatu kegiatan atau untuk menyelesaikan sasaran tertentu. Sedangkan pendekatan sistem yang lebih menekankan pada elemen atau komponennya mendefinisikan sistem sebagai kumpulan dari elemen-elemen yang berinteraksi untuk mencapai suatu tujuan tertentu.

\section{b. Pengertian Informasi}

Informasi merupakan hal yang sangat penting dalam sebuah organisasi ataupun institusi. Suatu sistem yang kurang mendapatkan informasi akan menjadi kecil dan akhirnya berakhir. Pengertian informasi dapat didefiniskan sebagai berikut :

"Informasi adalah data yang diolah menjadi bentuk yang lebih berguna dan lebih berarti bagi yang menerimanya." (Jogiyanto ,1999, hal 8)

\section{c. Pengembangan Sistem}

Pengembangan sistem ( System Development ) dapat berarti menyusun suatu sistem yang baru untuk menggantikan sistem yang lama secara keseluruhan atau memperbaiki sistem yang telah ada. Sistem yang lama perlu diperbaiki atau diganti dikarenakan beberapa hal seperti :

1. Adanya permasalahan - permasalahan ( Problem ) yang timbul di sistem yang lama. Permasalahan yang timbul dapat berupa :

a) Ketidak beresan dalam sistem yang lama menyebabkan sistem yang lama tidak dapat beroprasi sesuai dengan yang diharapkan.

b) Pertumbuhan Organisasi yang menyebabkan harus disusunnya sistem yang baru.

2. Untuk meraih kesempatan - kesempatan ( Opportunities ).

Dalam keadaan pasar bersaing dan berkembangnya teknologi mengharuskan penyajian informasi secara cepat dan efisiensi waktu yang menentukan berhasil atau idaknya strategi dan rencana - rencana yang telah disusun untuk meraih kesempatan yang telah disusun.

3. Adanya Instruksi - Instruksi (directives)

Penyusunan sistem yang baru dapat juga terjadi karena adanya instruksi - instruksi dari atas pimpinan ataupn dari luar organisasi.

\section{d. Metode pengembangan sistem}


Metode pengembangan sistem yang digunakan dalam penelitian ini adalah metode waterfall.

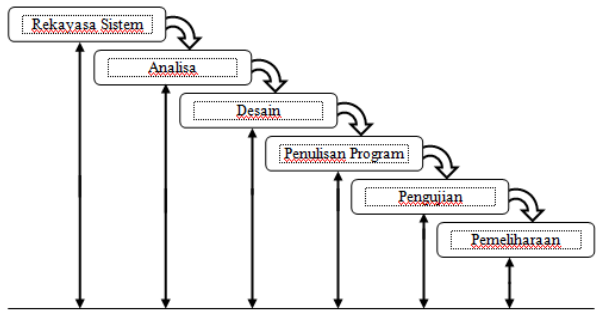

Gambar 2.1 Metode Waterfall

Tahapan model tersebut antara lain :

1. Rekayasa Sistem

Untuk mendapatkan gambaran yang meluas pada arus sistem dengan perangkat lunak merupakan bagian dari sebuah sistem. Tahapan dan tujuan akhir dibuat berdasarkan konsultasi dengan pengguna.

2. Analisis

Fokus lebih terarah pada perangkat lunak, menganalisis kebutuhan software dan hardware. Melibatkan pemakai dan pengembang.

3. Perancangan (Design)

Menerjemahkan persyaratan menjadi suatu bentuk representatif yang dapat dievalusi kualitasnya sebelum coding dilakukan.

\section{Penulisan Program (Coding)}

Menerjemahkan rancangan kedalam bentuk yang dapat dimengerti oleh komputer.

\section{Pengujiuan (Testing)}

Berfokus pada rincian logikal dari perangkat lunak, bertujuan mengungkap kesalahan-kesalahan yang ada sehingga perangkat lunak bekerja sesuai dengan yang diharapkan.

\section{Pemeliharaan (Maintenance)}

Meliputi kegiatan-kegiatan koreksi kesalahan dan penyesuaian perangkat lunak terhadap perubahan lingkungannya.

\section{e. DFD (Data Flow Diagram)}

Menurut Andri Kristanto (2003:55) pengertian Data Flow Diagram sebagai berikut:

DFD adalah suatu logika data atau proses yang dibuat untuk menggambarkan dari mana asal data dan kemana arah tujuan data yang keluar dari sistem, dimana data disimpan, proses apa yang menghasilkan data tersebut dan interaksi antara data yang tersimpan dan proses yang dikenakan pada data tersebut.

\section{f. Pengembangan Multimedia}

Pengembangan Multimedia dilakukan dengan enam tahap yaitu concept, desain, material corecting, assembly, testing dan distribution.

\section{g. Microsoft Visual Basic 6.0}

Menurut Adi Kurniadi (2001:1) Visual Basic adalah salah suatu development tools untuk membangun aplikasi dalam lingkungan Windows. Dalam pengembangan aplikasi, Visual Basic menggunakan pendekatan Visual untuk merencanakan user interfase dalam bentuk form, sedangkan untuk kodingnya menggunakan dialek bahasa basic yang cenderung mudah dipelajari. Visual Basic menjadi tools terkenal bagi para pemula maupun para developer. Dalam lingkungan Widows User-interface sangat memegang peranan penting, karena dalam pemakaian aplikasi yang kiat buat, pemakaian senantiasa berinteraksi dengan User-interface tanpa menyadari bahwa dibelakangnya berjalan instruksi-instruksi program yang mendukung tampilan dan proses yang dilakukan. Pada pemrograman Visual, pengembangan aplikasi dimulai dari pembentukan user interface, kemudian mengatur properti dari objek-objek yang digunakan dalam user interface dan baru dilakukan penulisan kode program untuk menangani kejadian-kejadian (event). Tahap pengembangan aplikasi demikian dikenal dengan istilah pengembangan aplikasi dengan pendekatan Bottom Up.

\section{h. Macromedia Flash Versi 8}

Macromedia Flash adalah salah satu program animasi grafis yang banyak digunakan para desainer untuk menghasilkan karya-karya professional, khususnya bidang animasi. Program ini cukup fleksibel dan lebih unggul dibandingkan program animasi lain sehingga banyak animator yang memakai program tersebut untuk pembuatan animasi.

Keunggulan macromedia flash disbanding program yang lain:

1. Membuat tombol interaktif dengan sebuah movie atau objek yang lain.

2. Membuat perubahan transparansi warna dalam movie. 
3. Membuat perubahan animasi dari satu bentuk kebentuk lain.

4. Membuat gerakan animasi dengan mengikuti alur yang telah ditetapkan.

5. Dikonvesri dan dipublikasikan kedalam beberapa tipe, diantaranya adalah .swf, .html, .gif, .png, .exe, .mov.

\section{METODOLOGI PENELITIAN}

Metodologi penelitian yang digunakan dalam penelitian ini adalah bersifat deskriptif yaitu suatu metode untuk mengemukakan masalah dengan mengumpulkan data - data dan menyajikan data yang tujuannya menggambarkan karakterisitik suatu keadaan atau objek penelitian dan mengambil kesimpulan yang telah dilakukan.

\section{a. Kebutuhan Sistem}

Kebutuhan untuk menjalankan sistem dibagi menjadi dua bagian yaitu kebutuhan perangkat keras dan kebutuhan perangkat lunak.

\section{Implementasi perangkat keras yang digunakan dalam merancang visualisasi pembelajaran tajwid dalam membaca Alqur'an berbasis multimedia ini memiliki spesifikasi : \\ 1. Processor intel Celeron, $1.80 \mathrm{GHz}$. \\ 2. Random Acces Memory (RAM) $256 \mathrm{MB}$. \\ 3. Harddisk 80 GB. \\ 4. Keyboard dan mouse \\ b. Diagram Konteks}

Diagram konteks berfungsi menjabarkan sistem secara garis besar dan keseluruhan sebagai suatu kesatuan yang berhubungan antara input dan output dengan kesatuan luarnya.

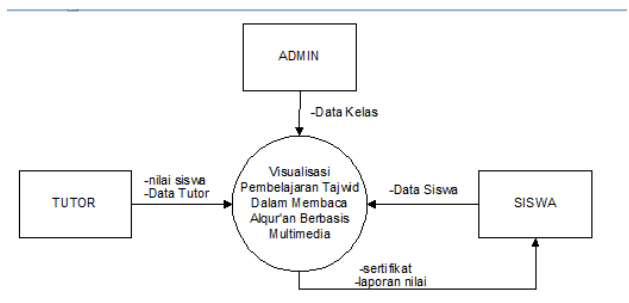

Gambar 3.1 Diagram Konteks

\section{c. Relasi Antar Tabel}

Relasi antar tabel berfungsi untuk menggambarkan hubungan antara tabel-tabel didalam basis data. Adapun bentuk dari relasi antar tabel pada penelitian ini adalah sebagai berikut :

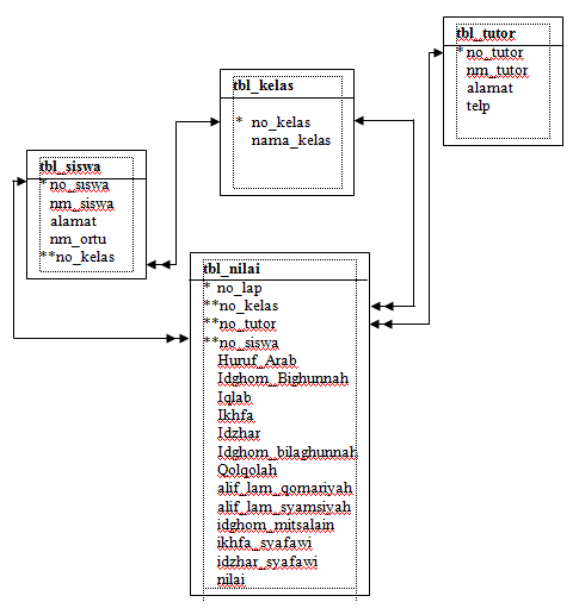

Gambar 3.2 Relasi Antar Tabel

\section{d. Rancangan Halaman Utama}

Berikut ini adalah tampilan dari Halaman Utama pada sistem :

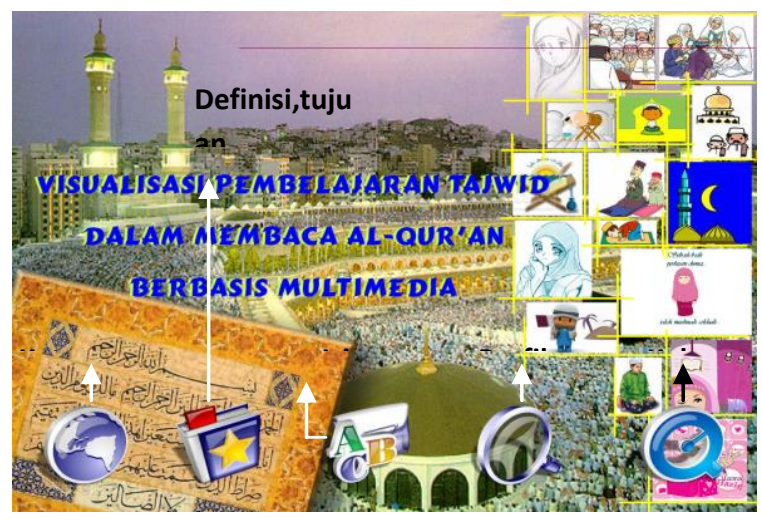

Gambar 3.3 Rancangan Tampilan Halaman Utama

\section{e. Rancangan Halaman Definisi dan Tujuan Ilmu Tajwid}

Berikut ini adalah tampilannya :

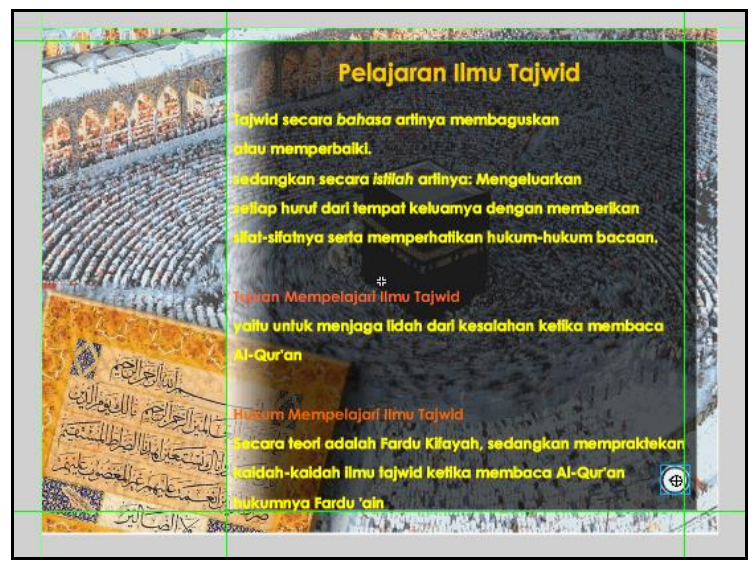


Gambar 3.4 Rancangan Tampilan Halaman Definisi dan Tujuan Ilmu Tajwid

\section{f. Rancangan Halaman Huruf Hijaiyah}

Rancangan halaman Huruf Arab berisi penjabaran materi, lagu yang merupakan pemberian nada pada pembacaan huruf hijaiyah, ulang merupakan menu untuk mengulang ulasan materi dan kembali yaitu menu untuk kembali ke menu utamanya. Rancangannya sebagai berikut :

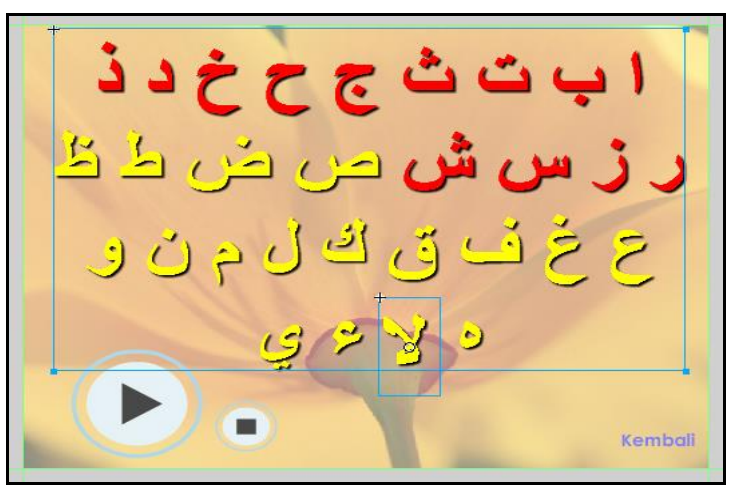

Gambar 3.5 Rancangan Tampilan Halaman Huruf Hijaiyah

\section{g. Rancangan Halaman Cara Melafalkan}

Rancangan halaman cara melafalkan terrdiri dari penjelasan materi dan menu kembali untuk kembali ke bagian menu sebelumnya. Berikut rancangannya :

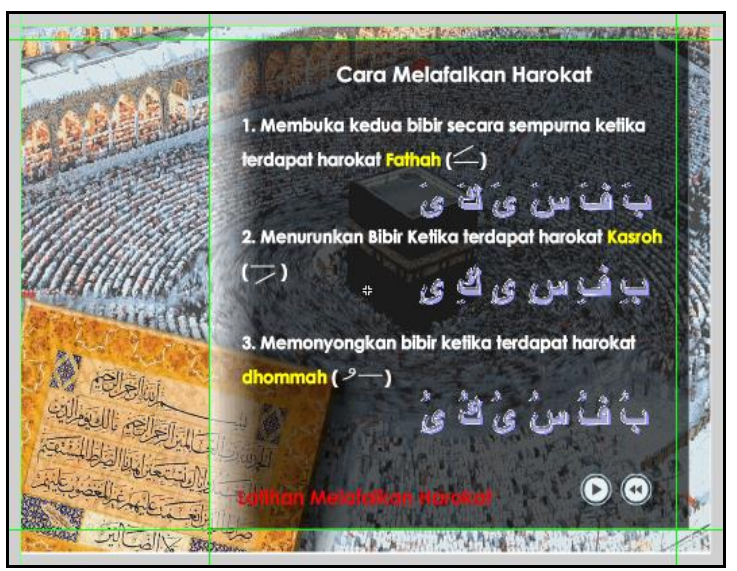

Gambar 3.6 Rancangan Cara Melafalkan

\section{h. Rancangan Halaman Profil}

Berikut ini adalah tampilan dari Halaman Profil pada sistem :

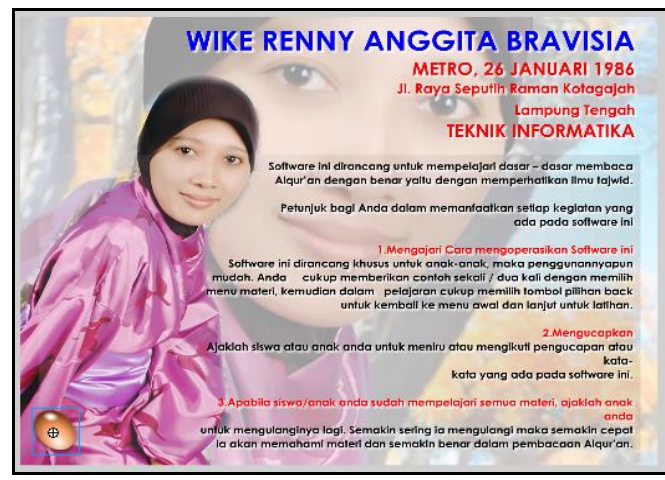

Gambar 3.7 Rancangan Tampilan Halaman Profil

\section{i. Tahap Implementasi Program}

Implementasi Program menggunakan software Macromedia Flash 8 dan Visual Basic 6.0. Macromedia Flash 8 digunakan untuk membuat suatu tampilan, gambar, animasi dan suara. Visual basic digunakan untuk pengolahan database.

\section{j. Konsep umum pengolahan pada tahap implementasi}

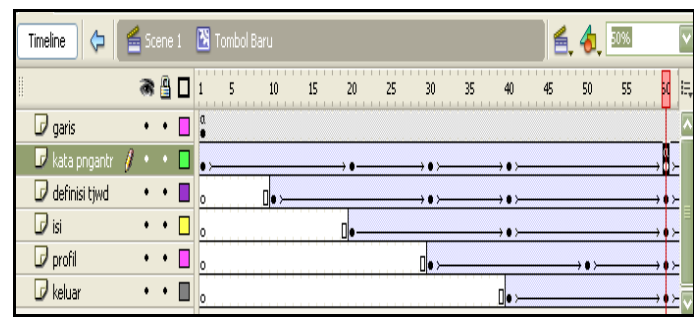

Gambar 3.8 Konsep Umum Pengolahan pada Tahap Implementasi

1. Penggunaan Timeline

2. Penggunaan Layer

3. Konsep simbol

4. Konsep Library

5. File Suara

k. Flowchart Program Menu Utama 
Berikut ini adalah bentuk flowchart pada Halaman utama :

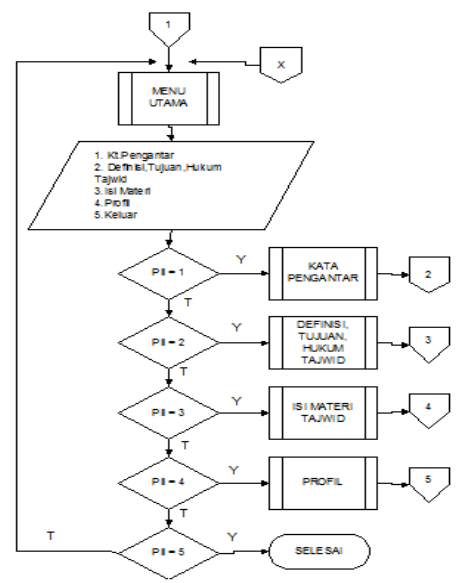

Gambar 3.9 Flowchart Program Menu Utama

\section{KESIMPULAN DAN SARAN}

\section{a. Kesimpulan}

Bab ini akan menjelaskan beberapa simpulan sehubungan dengan uraian yang telah dijelaskan pada bab-bab sebelumnya dan saran bagi pengembangan sistem selanjutnya. Dengan memperhatikan program yang telah dibuat, maka didapatkan beberapa simpulan, yaitu :

1. Aplikasi Visualisasi Pembelajaran tajwid

Dalam Membaca Alqur'an berbasis multimedia ini digunakan sebagai alat bantu dalam pembelajaran tajwid bagi siswa di TPA sebagai dasar dari membaca Alqur'an.

2. Represenatsi materi dengan animasi dan suara memberikan kesan tersendiri bagi siswa. Teknik penyampaian materi pada aplikasi Visualisasi Pembelajaran Tajwid Berbasis Multimedia ini memberikan keuntungan beberapa aspek seperti kemudahan bagi para tutor untuk menyampaika materi, kemudahan para siswa dalam memahami materi dan dalam segi waktu dan tenaga akan lebih efisien.

\section{b. Saran}

Berdasarkan fakta yang telah diungkapkan sebelumnya, untuk memperbaiki masalah yang terjadi maka penulis mengajukan beberapa saran, diantaranya adalah sebagai berikut :

1. Aplikasi Visualisasi Pembelajaran Tajwid Dalam Membaca Alqur'an berbasis Multimedia ini ditujukan untuk anak - anak, diharapkan ada yang melanjutkan untuk pembelajran bagi orang dewasa dalam membaca Alqur'an dengan materi yang lebih dalam.

2. Perlunya peningkatan kemampuan para tutor dalam memahami aplikasi dari program yang dibuat untuk membantu kemudahan dalam proses belajar mengajar agar hasilnya maksimal.

\section{DAFTAR PUSTAKA}

1. BA Asyari, Abdullah, 1987, Pelajaran Tajwid (Qa'idah Bagaimana Seharusnya Membaca Alqur'an Untuk Pelajaran Permulaan), Surabaya : Apollo.

2. Daryanto,2003, Belajar Komputer Animasi Macromedia Flash, Bandung :Yrama Widia.

3. Edumedia, Faza, 2006, CD Pelajaran Tajwid Untuk Anak - Anak, FBP Record.

4. Firdaus, 2005, Pemrograman Database dengan visual basic 6.0 untuk orang awam,Yogyakarta : Maxicom.

5. H. M, Jogianto, 2001, Analisis Desain Sistem Informasi : Pendekatan terstruktur teori dan praktek aplikasi bisnis, Yogyakarta : Andi Yogyakarta.

6. Humam, KH. As'ad, 2005, Cara Cepat Belajar Tajwid Praktis, Yogyakarta :

7. Balai Litbang LPTQ Nasional Tadarus AMM. Informasi Tentang Pembelajaran Tajwid,http://www.ilma95.net/tajwid.htm

8. Kristanto, Andri, 2003, Perancangan Sistem Informasi dan Aplikasinya,

9. Yogyakarta : Gava Media, Edisi ke1.Kurniadi, Adi, 2001, Pemrograman Microsoft Visual Basic 6.0, Jakarta : Elex Media Komputindo. 